\title{
SULH (MEDIATION) IN THE STATE OF SELANGOR: AN ANALYSIS OF LEGAL PROVISION AND ITS APPLICATION
}

\author{
Sa'odah Binti Ahmad* \\ Nora Binti Abdul Hak**
}

\begin{abstract}
The first part of the paper seeks to examine the relevant legal provisions of sulh in the State of Selangor Darul Ehsan. Thus, the provisions of sulh as provided for under the Islamic Family Law Enactment 2003 will be discussed and analysed. Other provisions under the Administration of Islamic Religious Enactment 2003, the Syariah Court Civil Procedure Enactment 2003 and the Civil procedure (sulh) Rules 2001 will also be examined to study the procedures and guidelines in conducting Majlis sulth. The qualification of sulh officer will be briefly discussed in the last part of the paper. The paper concludes by commending the initiative that has been taken by the Department of Syariah Judiciary of Selangor in introducing sulh which has been proven to be very effective in reducing excess cases in the State Syariah Courts.
\end{abstract}

Keywords: Islamic Law, ADR, Sulh, Family Law, Shariah Court.

\footnotetext{
* Lecturer, Faculty of Human Ecology, University Putra Malaysia.

** Associate Professor, Ahmad Ibrahim Kulliyyah of Laws, IIUM.
} 


\section{INTRODUCTION}

One of the resolutions of a national seminar on Alternative Dispute Resolution held on $4^{\text {th }}$ and $5^{\text {th }}$ February 2002 by Legal Division of the Prime Minister Department, Putrajaya was to enhance the use of mediation in all matters. It was suggested that a law pertaining to mediation be enacted and mediation should be introduced at grassroots level. ${ }^{1}$ Responding to this resolution and in view of the importance of sulh as an alternative method in settling disputes amicably (particularly in family disputes), the Selangor Syariah Courts introduced Majlis Șulh in 2002.

Today, Selangor is the most proactive and successful state in Malaysia in implementing the law and procedures on sulh relating to family disputes. The law has been enforced here since 2002. With regards to the effectiveness of sulh in 2003, 90\% of cases registered in the Syariah Courts of Selangor were settled through Majlis Sulh. ${ }^{2}$ The previous Chief Minister of Selangor, Datuk Seri Dr. Mohamad Khir Toyo stated that Majlis Șulh undoubtedly plays a vital role both in minimizing backlog cases $^{3}$ and speeding up settlement of cases in Syariah Courts. ${ }^{4}$

$1 \quad$ Legal Division of the Prime Minister Department, Putrajaya $<$ http:// www.bheuu.gov.my $>$ viewed on $6^{\text {th }}$ June 2006.

2 “Majlis Ṣulh Selesai 90\% Kes Syariah,” Berita Harian, $2^{\text {nd }}$ May 2003, 4.

3 By 2002 there were an excess of 35,017 civil cases awaiting settlement in the Syariah Court all over Malaysia. See "Șulḥ Kaedah Pilihan Utama Atasi Pertikaian,” Berita Harian, $15^{\text {th }}$ August 2002, 13.

4 Ibid. 
Table 1.1: Statistic of Sulh: The Department of Syariah Judiciary Selangor (JAKESS) May 2002 to December 2006

\begin{tabular}{|l|c|c|c|c|}
\hline $\begin{array}{c}\text { Syariah Court (High } \\
\text { Court \& Lower } \\
\text { Court) }\end{array}$ & $\begin{array}{c}\text { Registered } \\
\text { Cases }\end{array}$ & Sul & $\begin{array}{c}\text { Referred For } \\
\text { Trial By Court }\end{array}$ & Adjourned \\
\hline High Court & 1583 & $\mathbf{5 5 4 ( 3 5 \% )}$ & $910(57 \%)$ & $119(8 \%)$ \\
\hline Shah Alam & 670 & $\mathbf{3 7 1}(\mathbf{5 5 \% )}$ & $283(42 \%)$ & $16(3 \%)$ \\
\hline Klang & 1345 & $\mathbf{1 1 1 2 ( 8 3 \% )}$ & $233(17 \%)$ & $0(0 \%)$ \\
\hline Kuala Langat & 426 & $\mathbf{3 4 4 ( 8 0 \% )}$ & $80(19 \%)$ & $2(1 \%)$ \\
\hline Kuala Selangor & 488 & $\mathbf{3 2 8 ( 6 7 \% )}$ & $152(31 \%)$ & $8(2 \%)$ \\
\hline Sabak Bernam & 254 & $\mathbf{2 2 1 ( 8 7 \% )}$ & $33(13 \%)$ & $0(0 \%)$ \\
\hline Petaling Jaya & 983 & $\mathbf{6 5 4 ( 6 6 \% )}$ & $325(33 \%)$ & $4(1 \%)$ \\
\hline Gombak Barat & 361 & $\mathbf{2 4 5 ( 6 8 \% )}$ & $107(30 \%)$ & $9(2 \%)$ \\
\hline Gombak Timur & 376 & $\mathbf{2 3 5 ( 6 3 \% )}$ & $137(36 \%)$ & $4(1 \%)$ \\
\hline Sepang & 280 & $\mathbf{2 1 3 ( 7 6 \% )}$ & $67(24 \%)$ & $0(0 \%)$ \\
\hline Hulu Selangor & 243 & $\mathbf{1 6 7 ( 6 9 \% )}$ & $73(30 \%)$ & $3(1 \%)$ \\
\hline TOTAL & $\mathbf{7 8 7 2}$ & $\mathbf{5 0 4 4 ( 6 4 \% )}$ & $\mathbf{2 6 4 5 ( 3 4 \% )}$ & $\mathbf{1 8 3 ( 2 \% )}$ \\
\hline
\end{tabular}

Source: JAKESS < http://jakess.gov.my

Sulh is undoubtedly a very constructive method of resolving disputes. This is evident in the statistic of sulh provided by JAKESS as shown in Table 1.1. The successful rate of sulh was 64\% as compared to $34 \%$ cases referred for trial. The rate of adjourned cases was only $2 \%$. The complexity of the cases was found to be the main reason for adjournment because the cases could not be settled just in one Majlis 
Șulh (by marathon). ${ }^{5}$ In addition, the living status of the parties, the level of their education and the tight schedule of the court contributed to a larger number of cases registered for sul $h$, in addition to being contributing factors to adjournment of cases. ${ }^{6}$ By implementing sulh the Syariah Courts of Selangor not only managed to resolve disputes amicably but are also able to unclog the court calendar.

\section{PROVISIONS ON ȘULH IN THE STATE OF SELANGOR}

In general, the application of sulh in Selangor is governed by these laws and procedures:

- $\quad$ The Administration of Islamic Religious Enactment 2003.

- $\quad$ The Syariah Court Civil Procedure Enactment 2003.

- $\quad$ The Civil Procedure (Șulh) Rules 2001.

- $\quad$ The Islamic Family Law Enactment 2003.

- The Sulh Work Manual, Department of Syariah Judiciary, Malaysia (JKSM) 2002.

- $\quad$ The Sulh Officer Ethical Code, JKSM 2002.

- $\quad$ The Selangor Syariah Court Chief Justice General Order 9/2002 [Jurisdiction of Șulh Officer (Judge)].

- $\quad$ The Practice Direction JKSM 3/2002 (Application of Șulh).

- $\quad$ The Practice Direction JKSM 7/2002 (Method of Storing and Dissolving Șulh Record).

- $\quad$ The Practice Direction JKSM 8/2002 (Șulḥ Notice Procedure).

Below are discussions on some of the important provisions that govern sulh in the state of Selangor.

The Islamic Family Law Enactment 2003 (Selangor) (IFLE 2003)

\section{a. Section 47}

The provisions relevant to sul $h$ are contained in section 47 and 48 of the IFLE 2003. According to section 47(5):

\begin{tabular}{ll}
\hline 5 & Ibid. \\
6 & Ibid.
\end{tabular}


"Where the other party does not consent to the divorce or it appears to the court that there is reasonable possibility of a reconciliation between the parties, the court shall, as soon as possible, appoint a conciliatory committee consisting of a religious officer as Chairman and two other persons, one to act for the husband and the other for the wife, and refer the case to the committee.

The above provision illustrates that in the case of contested divorce, a religious officer will be appointed to chair a conciliatory committee. The word 'religious officer' is not defined by the IFLE 2003. However, in practice the Chairman is usually the Head of Family Counselling and Development Unit or the Head of Registration of Marriage, Divorce and Revocation Unit in the Department of Islamic Religion of Selangor. In 1988, the Melaka Syariah Court decided that a reconciliation conducted by the army religious officer was valid. ${ }^{7}$ In other words, the judge in this case held an opinion that an army religious officer fell within the ambit of 'religious officer' provided by section 47 of IFLE 2003.

The Chairman is assisted by representatives of the husband and the wife who are usually their relatives. In the event of unavailability of relatives, the court will appoint respected people in the community such as imäms, to represent the parties in dispute. The representatives will be guided by the court on the conduct of the conciliation. The committee is given six months to settle the case. ${ }^{8}$ If the settlement could not be achieved or the court is not satisfied with the performance of the committee, another committee will be appointed. Parties that are successfully reconciled will resume their conjugal relationship and the court will dismiss the divorce application. However, if reconciliation failed, the committee will issue a certificate to that effect to the court. The court will ask the husband to pronounce one talāq. If the court is unable to procure the presence of the husband, the case will be referred to hakam. ${ }^{9}$ 
The importance of complying with section 47 can be seen in the case of Razimah Haneem v Yusuf Hasbullah. ${ }^{10}$ The husband petitioned for divorce under section 47. As it was a contested divorce, a conciliatory committee was appointed. During the proceeding, the husband pronounced talāq out of court. The pronouncement was duly witnessed but in the absence of the wife. The wife only knew about it two months later. The trial judge confirmed the taläq by relying solely on the husband's statement that he had divorced his wife. The Syariah Appeal Court set aside the judgement of the trial court and ordered a retrial so that requirement of section 47 could be fulfilled.

The application of section 47 is however exempted in the following cases: ${ }^{11}$

(a) Where the applicant alleges that he or she has been deserted by and does not know the whereabouts of the other party.

(b) Where the other party is residing outside Peninsular Malaysia and it is unlikely that he or she will be within the jurisdiction of the court within six months after the date of the application.

(c) Where the other party is imprisoned for a term of three years or more.

(d) Where the applicant alleges that the other party is suffering from incurable mental illness.

(e) Where the court is satisfied that there are exceptional circumstances which make reference to a conciliatory committee impracticable.

From a scrutiny of section 47 , there is no specific or detailed provisions that govern the conduct and ethics of the committee members as well as their qualification to effect reconciliation. The difficulty arises if members of the conciliatory committee, particularly representatives of the parties, do not really comprehend the committee's objective and their responsibility in the reconciliation process. ${ }^{12}$ It is not uncommon that the

\footnotetext{
$10 \quad$ (1993) 9 JH 237.

11 These exemptions are similar to provisions in section 106 of the Law Reform (Marriage and Divorce) Act 1976, which provides for reference to conciliatory committee for non-Muslim.

12 Nadia Khamis, Sulh officer in Sepang Lower Syariah Court, interviewed by author, $11^{\text {th }}$ September 2007.
} 
representatives take the approach of defending the parties whom they represent, which they should not. ${ }^{13}$

This will create difficulty in managing the dispute and in the end reconciliation will never take place. ${ }^{14}$ Therefore, it is suggested that these loopholes should be addressed in order to improve the effectiveness of the committee in conducting reconciliation. The committee should be informed and reminded about their responsibility and the importance of being neutral while conducting the reconciliation.

\section{b. Section 48}

The implementation of sul $h$ in the form of tahkim is sanctioned by Section 48, which provides that if the court is satisfied that there are constant quarrels between the parties to a marriage, the court may order the appointment of two hakams, one to act for the husband and another for the wife. The authority for this provision is derived from the Qur'ān, al- Nisā': 35, which provides to the effect:

"If you fear a breach between them (the man and his wife), appoint two arbitrators, one from his family and the other from hers; if they both wish for peace, Allah will cause their reconciliation. Indeed Allah is Ever All knowing, well Acquainted with all things."

As discussed above, section 47 provides that hakam may also be appointed if the conciliatory committee fails to reconcile the parties in a contested divorce and subsequently in the event where the husband could not be ordered to pronounce talāq in court. It is observed that section 47(5) practically leads to the non-application of section 48 . This is in concurrence with Nora's observation based on her research at the Family Counselling and Development Unit of the Islamic Religious Department of Federal Territory, which highlighted the court's practice

13 Ibid; see also, Nora Abdul Hak, Islamic arbitration (tahkim) and mediation in resolving family disputes: A comparative study under Malaysian and English law, (Ph.D. thesis, Glasgow Caledonian University, 2002) at 136.

$14 \quad$ Ibid. 
of resorting to Conciliatory Committee rather than hakam due to the difficulty of getting people with the qualification of hakam. ${ }^{15}$ Her observation is in line with Azizah who asserts that in reality, the function of hakam in section 48 is in fact by the Conciliatory Committee. ${ }^{16}$

In practice, parties in dispute were only referred to Conciliatory Committee after they had failed to be reconciled by the Family Counselling and Development Unit of the Islamic Religious Department. ${ }^{17}$ This inadvertently led to the failure of conciliation between the parties. Nora also argues that the absence of the definition of shiqāq (marital discord) or circumstances qualifying shiqāq in section 48 resulted in judges' cautious interpretation of the word and that caused them to decide eventually that there was no shiqāq in the case. ${ }^{18}$ Consequently, the need for hakam does not arise.

It is noted that there are differences between section 47 and 48 of the IFLE 2003 Firstly, Conciliatory Committee is chaired by a religious officer from the Islamic Religious Department whereas tahkim is conducted by the appointed hakam. ${ }^{19}$ Secondly, hakam has the power to effect divorce even in the case where the husband refuses to do so while the Chairman of Conciliatory Committee has no such power. Thus, it is observed that hakam is an arbitrator rather than a mediator.

\section{The Syariah Court Civil Procedure Enactment 2003 (Selangor) (SCCPE 2003) ${ }^{20}$}

Another law that provides for sulh in Selangor is SCCPE 2003. The relevant provisions are discussed below;

\footnotetext{
$15 \quad$ Nora, n. 13 at 135.

16 Azizah binti Mohd Rapini, Fungsi Hakam dan Keberkesanannya dalam Menyelesaikan Krisis Rumahtangga: Satu Kajian di Daerah Klang, Selangor, (unpublished academic exercise, Akademi Pengajian Islam Universiti Malaya 1988) 66.

$17 \quad$ Nora, n. 13 at 135.

18 Ibid.

19 The court prefers close relatives who know the circumstances of the dispute to act as hakam-section 48(1) IFLE 2003.

20 This enactment amended the Syariah Court Civil Procedures (Selangor) 1991, which provided for sulh in sections 87 and 88.
} 


\section{a. $\quad$ Section 99}

By virtue of section 99, any of the parties to a proceeding may convene sulh at any stage of the proceeding in order to resolve their dispute according to the established rules and procedure. In the absence of such rules and procedure, they can resort to hukum syarak. It is presumed that judges are encouraged to conduct sulh if they feel that there is possibility of reconciliation among the parties. It can be seen that in this situation, judges play an active role to effect mediation. The involvement of judges through informal meeting (sulh) with parties is highly needed in cases classified as urgent or chronic.

The importance of resorting to sulh as the correct approach to handle a case in court is illustrated in Norlia Bte Abd Aziz v. Md Yusof bin A Rahman, ${ }^{21}$ where Ismail Yahya J emphasized that when cases go to court, judges must first take step to effect mediation between the parties in dispute. However, the parties must be willing and are not coerced to enter into sulh. The plaintiff filed her statement of claim for jointly acquired property, praying for equal distribution of a double storey house in Damansara valued at RM260,000, a Proton Wira car valued at RM40,000, a Kancil car (no mention about the value) and a Honda C70 motorcycle valued at RM750. Pending the proceedings, three out of the four properties in dispute were successfully settled amicably by sul $h$. The only property that was contested in court was the double storey house.

It is observed that the judge in this case correctly followed the practice of previous judges who encouraged the disputants to volunteer for sul $h$ before proceeding to full trial. ${ }^{22} \mathrm{Al}$-Shāfi ' $\overline{1}$ was of the opinion that a judge may command the parties in dispute to attempt sulh. ${ }^{23}$ However, if the parties are reluctant to do so, he must proceed to adjudication. ${ }^{24}$ His opinion is supported by al-Șan'ānī, an eighteenth

\footnotetext{
$21 \quad$ [2004]5 MLJ538.

22 Ibid, especially when the disputants are related to each other and the case is complex.

23 Muḥammad ibn Idrīs al-Shāfi 'ī, Kitāb al-Aqḍiya in Al-Umm, Dār alKutub al-'Ilmiyya, 1995, vol. 6 at 312.

$24 \quad$ Ibid.
} 
century Ḥanafī jurist who pointed out that the Prophet Muhammad s.a.w himself resorted to reconcile the parties first before judging the dispute. ${ }^{25}$

Apart from reference to sul $h$ by judges, it is also normal that parties are referred to mediation by Syariah Counsels. ${ }^{26}$ In order to effect mediation, the counsels normally ask permission of the court to postpone the hearing. ${ }^{27}$ In granting the postponement, the court usually reminds the parties and counsels to uphold justice at all time during the process of sulh..$^{28}$ The agreement reached in mediation is conveyed to the court and recorded as Consent Judgement. ${ }^{29}$

The role played by the Syariah Counsels in effecting sulh is illustrated by the case of Zailan bt Mohamad v. Mohd Ariff $b$. Ali. ${ }^{30}$ The plaintiff and the defendant married in 1980 and went to further their studies abroad. Upon completion of their study, they came back to Malaysia. They were blessed with four children. The defendant failed in his responsibility to maintain the plaintiff and their children. The plaintiff also found out that the defendant was involved with another woman and for the past three years, they had ceased their relationship as husband and wife. Unable to bear with the circumstances anymore was the key factor that caused the plaintiff to apply for fasakh in court. During the trial, both counsels advised the plaintiff and the defendant to settle their dispute through sul $h$. As a result, the disputants opted for a settled divorce and mutually agreed that;

- $\quad$ The custody of children is given to the plaintiff.

- $\quad$ The defendant pays RM1500 per month for maintenance of the children.

- $\quad$ The plaintiff waives her rights to muta'ah and 'iddah maintenance.

- $\quad$ The matrimonial home is sold and the profit divided equally between them.

$25 \quad$ The relevant tradition is pertaining to the case of Zubayr al-'Awwām and an Anșār man over irrigation of their orchards.

26 Mohd Na'im Bin Hj Mokhtar. "Administration of Family Law in the Syariah Court,” vol. 3 (2001) MLJ lxxxi.

27 Ibid.

28 Ibid.

29 Ibid.

30 Unreported civil case No. 12/2000, Syariah Court of Petaling Jaya. 
This case demonstrates that Syariah Counsels can also play an active role in encouraging settlement of dispute by sulh. They can advise their clients to opt for sulh either at the initial stage of the case or during the trial itself provided before the judgment is made. Amicable settlement should be resorted in cases that involve high risk of conflicting interest and animosity among the disputants like what happened in the above case.

However, it is to be noted that sulh effected by Syariah Counsels normally happen at the later stage of the trial or sometime during an appeal. ${ }^{31}$ This is to say that the disputants have already incurred expenses as the case has proceeded for litigation in court. Therefore, it is much more beneficial for the parties in dispute to resort to sul $h$ at the early stage of the case. That is one of the reasons why in the state of Selangor, parties in dispute are directed to sul $h$ by the court. In other words, the application of sul $h$ in the state of Selangor is court-based.

\section{b. $\quad$ Sections 94 and 131}

Section 94 provides for the recording of settlement reached in any proceeding including șulh. According to this section, settlement agreed by sul $h$ will be recorded:

"Where by agreement of the parties an action has been settled, the Court may, at any time by consent of the parties, record the fact of such settlement with the term thereof. The record of settlement shall afford as a defense by way of res judicata to subsequent proceeding."

The similar provision is seen reiterated in section 131 . This section provides for Consent Judgement. According to section 131, judgement based on consent or agreement of the parties, including parties in sulh, may be recorded by the Court at any time.

It is observed that according to sections 94 and 131, the validity of any agreement between the parties depends on whether it has been

$31 \quad$ Kv. S (1991) 7 JH (2) 162. 
endorsed by the court or not. If the court has endorsed the agreement as consent judgment, it is valid for enforcement and failure to abide by it will amount to contempt of court. An example of this requirement can be seen in the case of Sharifah Zaharah v Juatan Hussain. ${ }^{32}$ The parties divorced in 1983. They had four children. They made an amicable settlement resulting in an agreement witnessed by two Islamic Religious Council officers and a Sibu Syariah Court judge.

The defendant agreed to pay RM150 per month (for children maintenance) until the children reach 18 years of age. Upon defendant's failure to pay the maintenance, the plaintiff applied for the enforcement of the agreement under section 84 of the Islamic Religious Council Ordinance 1978 (IRCO 1978). The Kadi Court of Sarawak dismissed the application and held that the agreement was an ordinary agreement and not amounting to a consent judgment. In other words, the agreement was never endorsed by the court as in the case of consent judgment affected by sulh. Therefore section 84 of IRCO 1978 which provides for enforcement of court judgment or order was inapplicable.

In Ahmad Ismail v. Mariani Khaled ${ }^{33}$ the parties were married in 1984 and divorced in 1995. They had two sons aged 9 and 5 respectively. Both agreed that the custody of the first son be given to the plaintiff and the second son to the defendant. The same visitation rights were given to them and they could bring home the child who was not in their custody twice a month. The plaintiff was denied his right of visitation by the defendant. The plaintiff applied for the court enforcement order under section 220 of SSCSPE 1991 which provides for fine or imprisonment due to contempt of court. The case went for trial in 1997 and during the trial the judge advised parties to solve the matter amicably (sulh). The parties agreed and consent judgment was made to the effect.

Based on the above discussion, it can be concluded that there was no detailed and specific provision in SCCPE 2003 which direct the court or Syariah Counsels to refer cases to a special body for mediation. Hence, judges and Syariah Counsels at their own initiative encouraged the parties in dispute to consider sulh. They were guided by principles of Islamic law as sanctioned by section $245 .^{34}$ This section provides that in

\footnotetext{
$32 \quad$ (1989) 6 JH(2) 254.

33 Civil case 179/97 Petaling Jaya Lower Syariah Court.

$34 \quad$ Section 245(2) SCCPE 2003.
} 
the event of a lacuna or in the absence of any matter not expressly provided by SCCPE 2003, the court shall apply Islamic law.

\section{The Syariah Civil Procedure (Șulh) Rule 2001 (SCCPSR 2001)}

Realizing the difficulty of enforcing sul $h$ without proper guidelines resulted in the enactment of SCCPSR in 2001. The law was only enforced throughout Selangor in 2002. In order to facilitate the application of sulh, ten Syariah Officers (Grade L41) ${ }^{35}$ were appointed on a contract basis to serve as mediators in the Lower Courts and one in the High Court. ${ }^{36}$

\section{a. Application}

The SCCPSR 2001 was enforced on $1^{\text {st }}$ August 2001. With regards to its application, Rule 1(2) provides that SCCPSR 2001 does not cover the application of divorce under IFLE 2003. In other words, sul $h$ is not a process where the parties discuss whether to divorce or not but it is a process to settle matters arising out of divorce such as muta 'ah, harta sepencarian, 'iddah maintenance, hadānah and maintenance of children. ${ }^{37}$ As of 2006, sulh on hadānah, harta sepencarian and

$35 \quad$ As of January 2009, there were twelve Șulh Officers in Selangor Syariah Courts. They are: SM Jamil Ahmad - LSC Petaling, SM Mohd Nurulazhar Mohd Tohar - SHC Shah Alam, SM Azmi Aziz - MRS Klang, SM Mohd Fazil Hassan - LSC Hulu Langat, SM Khairul Azwadi Mohd Nor - SHC Shah Alam, Nadia Khamis - LSC Kuala Langat, Siti Noraini Mohd Ali LSC Gombak Timur, SM Abdul Halim Abu Samah - LSC Gombak Barat, SM Kamarulzaman Ali - LSC Shah Alam, SM Norafizi Fitri Ab Manaf LSC Kuala Selangor, Tuan Mohd Ridzuan Zainuddin - Research Officer for Chief Justice Syarie and Salmi Amalia Jamil - Research Officer SHC Shah Alam.

Sheikh Ghazali Abdul Rahman, "Penyelesaian Kes-kes Kekeluargaan Islam Melalui Manual Kerja Șulh," paper presented in Seminar Keperluan Manual Mengenai Undang-Undang Keluarga Islam, 3-4 September 2002, IKIM, 6-8. Presently, Sulḥ Officers are appointed on permanent basis.

37 Mohamad Ridzuan, a Research Officer/Ṣulh Officer of Selangor Syariah High Court, correspondence with the researcher, $6^{\text {th }}$ August, 2007. Cases 
polygamy are no longer conducted by the Lower Syariah Courts. ${ }^{38}$ The jurisdiction to conduct sul $h$ in these matters is given to the Syariah High Court at Shah Alam.

In practice, sulh may arise from the application for divorce or confirmation of divorce..$^{39}$ In this situation, the Registrar will take action to ensure that parties have already decided to divorce and agree to settle claims arising thereof by way of sulh. ${ }^{40}$ In other words, discussion on whether to divorce or not to divorce will never take place in sulth.

However, this procedure is only applicable to cases brought by the parties themselves or cases referred by judges after considering that such cases can be properly settled by sulh..$^{41}$ Parties will be required to fill in the appropriate form that specifies their consent to settle disputes arising out of divorce by sul $h$. If the application was brought by legal

that can be resolved by sulh as provided by the Islamic Family Law Enactment (Selangor) 2003 among others are:

a) Section 13 - Consent of wālì (guardian).

b) Section 18(1)(c) - Wālī hakim

c) Section 23(1) - Polygamy

d) Section 47 - Application of divorce

e) Section 49 - Khulu'

f) Section $50-$ Ta liq.

g) Section 53 - Fasakh

h) Section 57 - Confirmation of divorce

i) Section 58 - Mut'ah

j) Section 60 - Maintenance of wife

k) Section 61 - The power of court to order maintenance

l) Section 66 - 'Iddah maintenance

m) Section 67 - Amendment of wife maintenance order

n) Section 70 - Outstanding maintenance

o) Section 73 - Mainternance of children

p) Section 82 - Custody of children

q) Section 122 - Harta sepencarian

r) Section 133 - Failure to abide maintenance order

s) Section 154 - Enforcement order

$38 \quad$ Nadiah Khamis, n. 12.

$39 \quad$ Sections 47 and 57 of the IFLE 2003.

$40 \quad$ Nadia Khamis, n. 12; Mohamad Ridzuan, n. 37; Abdul Halim Abu Samah, Șulh Officer of Lower Syariah Court of Gombak Barat, correspondence with the researcher, $3^{\text {rd }}$ August 2008.

Ibid. 
counsel, the normal procedure of settling the matters through court will be adopted. Thus, it is observed that by following the above procedure, the provision in Rule 1(2) is fulfilled.

\section{b. Determination of Date for Sulh}

According to Rule 3, if the Registrar, upon receiving any summon or application for any action, felt that there is reasonable possibility of reconciliation between the parties, he shall:

(a) Not determine the hearing date within three months from the registration date of the case;

(b) As soon as practical determine the date for șulh to be conducted between the parties; and

(c) Serve the notice with regard to the date of sulh to the parties.

Following the Customer Charter of JAKESS, the date will be determined on the case registration day itself and Majlis Șulh will convene in 21 days. Rule 3(c) emphasizes that the parties will be duly notified about the date of Majlis Șulh once it has been determined. Majlis Șulh refers to a mediation session where the disputants will discuss the issues in their dispute and try to settle them amicably. The following applications will be referred to Majlis Sulh for settlement:

- $\quad$ Application for breach of promise to marry (section 15 of IFLE 2003).

- $\quad$ Application for action arising out of divorce such as muta 'ah (section 58 of IFLE 2003), 'iddah maintenance (section 60 of IFLE 2003), outstanding maintenance (section 69 of IFLE 2003), harta sepencarian (section 122 of IFLE 2003), outstanding mahar (section 59 of IFLE 2003).

- $\quad$ Application for hadānah (section 82 of IFLE 2003).

- $\quad$ Application for children's maintenance (sections 73 and 74 of IFLE 2003).

- Application for enforcement of court order (section 154 of IFLE 2003).

- $\quad$ Any other application under section 99 of Syariah Civil Court Procedure Enactment (Selangor) 2003 (SCCPE 2003).

- $\quad$ Any other application under section 61(3)(b) of the Administration of Islam Enactment (Selangor) 2003. 


\section{c. $\quad$ Failure to attend Majlis Șulh}

Rule 4 specifies that, if any of the parties who are duly served with the Notice of Sul h fail to attend Majlis Sulh on the determined date, he or she is regarded as committing contempt of court which carries a penalty of not more than six months imprisonment or a fine not more than RM2000.

The penalty is clearly provided in Part XX1V of the SCCPE 2003, in particular section 229. It is presumed that this provision seeks to impose a duty on the disputing parties to treat Majlis Șulh as important as a court hearing.

\section{d. The process of Sulh}

Rule 5 provides the procedure for conducting Majlis Șulh. According to Rule 5(1) Majlis Șulh will be chaired by the Registrar or civil officer ${ }^{42}$ appointed by the Chief Syarie Judge. The parties will represent themselves. In other words, any other person including legal counsel is not allowed to attend Majlis Șulh unless with the permission of the Chairman/Șulh Officer. ${ }^{43}$ As mentioned above, Rule 4 prescribes that failure to attend Majlis Șulh is contempt of court and action will be taken against the party concerned.

The Chairman/Șulh Officer conducts Majlis Șulh based on the Sulh Work Manual 2002 (the Manual) and the Ethical Code of Șulh Officer (the Code) provided by JKSM. ${ }^{44}$ The Manual serves as a standard that defines the Sulth Officers or mediator's role, guide them in their day-to-day practice and protect consumers as well as the credibility of the profession. On the other hand, the Code prescribes ethics of the Sulh Officer. Failure to comply with the Code will result in disciplinary action under Civil Servant Rules (Behaviour) 1993, against the officer concerned.

\footnotetext{
42 Rule 2 of SCCPSR 2001 defines 'civil officers' as Registrar, Syari’ah Officer and Legal Officer appointed under section 3(2) Legal Aid Act 1971.

$43 \quad$ Rule 5(2) SCCPSR 2001.

$44 \quad$ JKSM<http://jksm.gov.my> viewed on $4^{\text {th }}$ March 2007.
} 
The Code imposes the following requirements on the Sulh officer: ${ }^{45}$

- Just.

- Neutral.

- $\quad$ Confidential.

- $\quad$ Avoid conflicting interest among the parties.

- $\quad$ Skilled in mediation.

- $\quad$ Conduct sulh only during healthy state of physical and mental for example not in anger, during hunger, or tiredness.

- $\quad$ Be patient, open and friendly to parties in dispute.

- $\quad$ No advertisement of his/her expertise.

- $\quad$ Cannot be witness or advisor to any of the parties that had undergone Majlis Șulh with him/her.

- $\quad$ Ensure the security of parties during Majlis Șulh.

According to the Manual, the Chairman/Ṣulh Officer is responsible to perform a brief $t a{ }^{\prime} \bar{a} r u f$ (introduction of self) session that will create conducive environment for sulh. In this session, the parties are encouraged to ask questions pertaining to syarak and Islamic Family law. This will help them understand the case and law better. The Chairman/Ṣulh Officer will inform the parties about the procedure of Majlis Șulh that includes: ${ }^{46}$

- $\quad$ Parties present their case according to their turn.

- When one party talks, the other should listen.

- $\quad$ Talk calmly without raising one's voice.

- $\quad$ Parties should act in good manner and avoid attacking each other.

- $\quad$ Parties are not allowed to communicate directly in the absence of the mediator.

- $\quad$ Parties must testify to follow stipulated rules before Majlis Șulḥ starts in order to ensure the smooth running of the process.

From the above discussion, it can be implied that Rule 5(3) SCCPSR 2001 requires the Chairman/Șulh Officer to help the parties in resolving their conflict by giving them the right to be heard, accepting

\footnotetext{
45 The Ethical Code of Șulh Officer, JKSM.

$46 \quad$ See, Chapter 3 of The Manual.
} 
relevant documents or if necessary, postponing the Majlis Sulh for the purpose of giving more time to parties to prepare for sulh or mediation.

After the plaintiff and the defendant have presented their case, the Chairman/Ṣulh Officer will arrange and manage the information to determine the issues to be resolved, the status and interest of the parties as well as the resolution to the problem at hand. ${ }^{47}$ The Chairman/Ṣulh Officer will advise the parties on his evaluation and lead the discussion/ negotiation between the parties. Parties are reminded not to blame each other and encouraged to come up with suggestions for resolution of the conflict. The Chairman/Șulh Officer must refrain from resolving the conflict himself, exercising justice at all time and maintaining the confidentiality of the process even to the court. ${ }^{48}$

According to Tuan Eizzul A'la Bajuri, ${ }^{49}$ one of the challenges faced by Șulh Officer is that sometimes the disputants do not have total confidence in them. They hire syarie lawyers before coming to sul $h$ and get advice from them. This results in the difficulty of accepting suggestions made by Șulh Officer. Eventually the mediation fails and the disputants decide to proceed for trial. Another problem is the misunderstanding of the disputants that Sulh Officer is the one who resolves the dispute whereas in reality the Sulh Officer plays the role of mediator who facilitates the discussion or mediation. ${ }^{50}$

Upon parties reaching full or partial agreement to resolve the issues in conflict, the Chairman/Sulh Officer will draft the agreement for settlement that will be signed by both parties. ${ }^{51}$ Before signing the agreement, the Chairman/Sul Officer may allow the parties to refer the agreement to their lawyer. However, he must also advise the parties not to be influenced by their lawyer to change the agreement. ${ }^{52}$ The agreement together with the report on Majlis Șulh will be presented to the court. The court will then endorse the agreement as Consent

\footnotetext{
$47 \quad$ Ibid.

$48 \quad$ Ibid.

49 Tuan Eizzul A’la Bajuri, previous sulh officer of Hulu Langat Lower Syariah Court, correspondence with researcher, $2^{\text {nd }}$ March 2007.

$50 \quad$ Ibid.

51 See, Chapter 5 (c), The Manual and Rule 6 of SCCPSR 2001.

52 See, Chapter 8 (d), The Manual.
} 
Judgement. With regards to partial agreement, the parties will bring forward the unresolved issues for court hearing. ${ }^{53}$

In the event where both parties fail to reach an agreement, the Chairman/Sulh Officer will make a report to the court. ${ }^{54}$ The court then will fix the hearing date. ${ }^{55}$ The case will follow the procedure for nonsulh cases as prescribed by the SCCPE 2003. An important thing that has been observed by the researcher is that, unlike adjudication process, there is no cost involved in sulh proceeding. ${ }^{56}$ It is presumed that this can be an added value to sulh as parties do not have to concern themselves with any expenses if they decide on resolving their issues by sulh.

\begin{tabular}{ll}
\hline 53 & See, Chapter 9, The Manual. \\
54 & See, Rule 7 of SCCPSR 2001. \\
55 & See, Rule 8 of SCCPSR 2001. \\
56 & See, Rule 9 of SCCPSR 2001.
\end{tabular}




\section{Figure 2.1: Sulh Work Process in the Selangor Syariah Court}

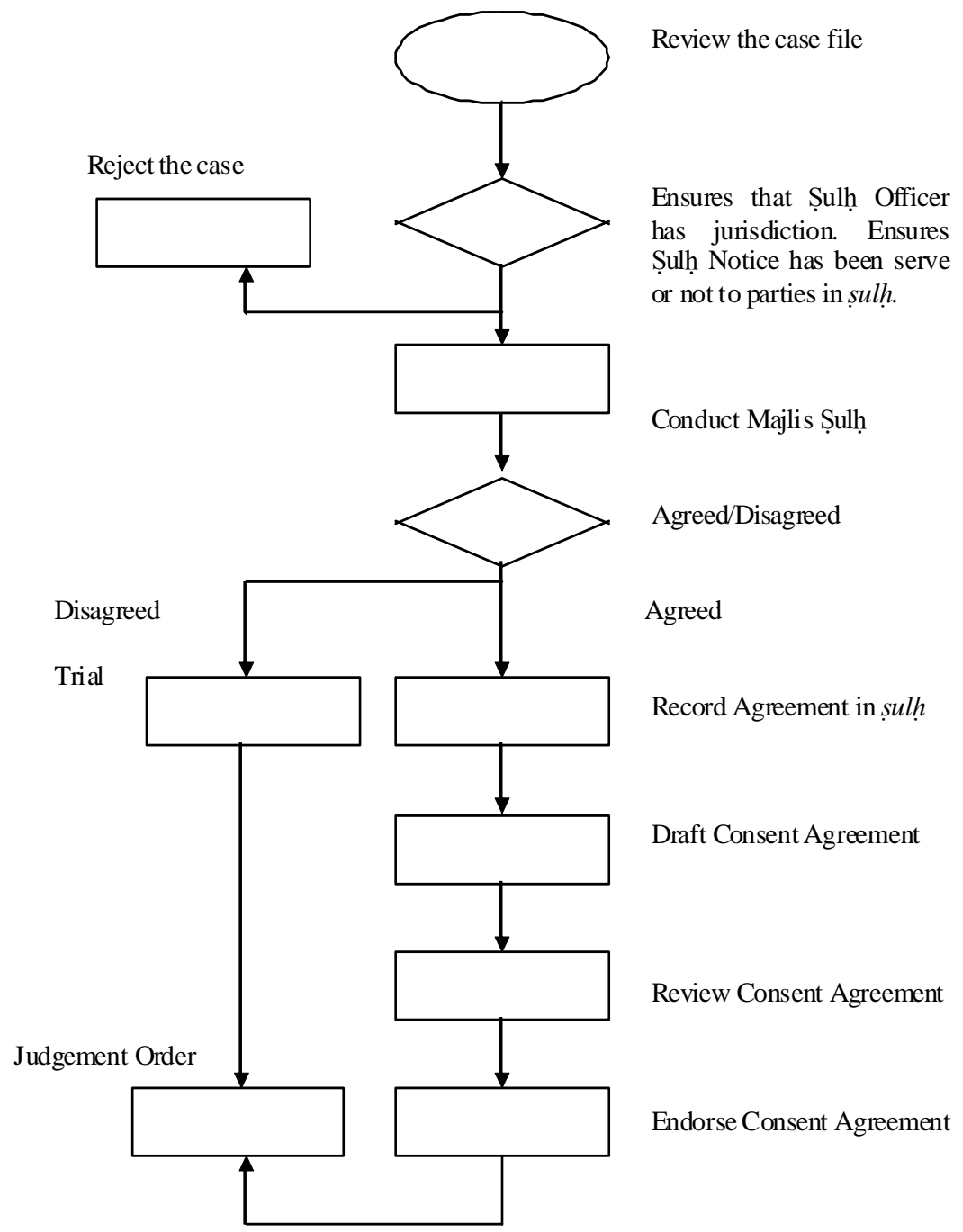

Source: <http://jksm.gov.my> 
Figure 2.2: Consent Agreement Work Process in the Selangor Syariah Court

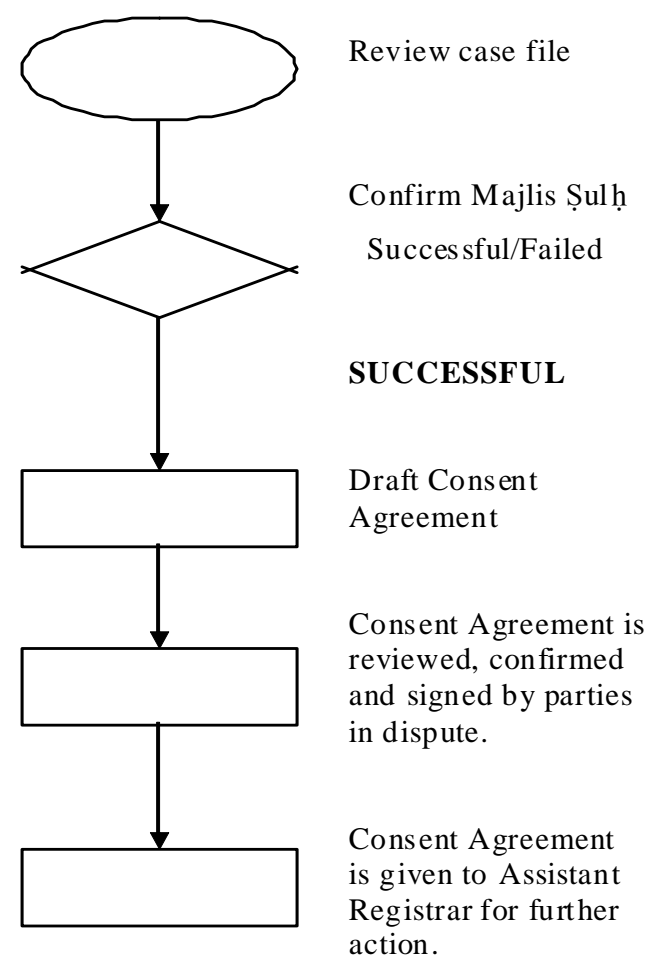

Source: Hulu Langat Lower Syariah Court 
Figure 2.3: Report of Majlis Sulh Work Process in the Selangor Syariah Court

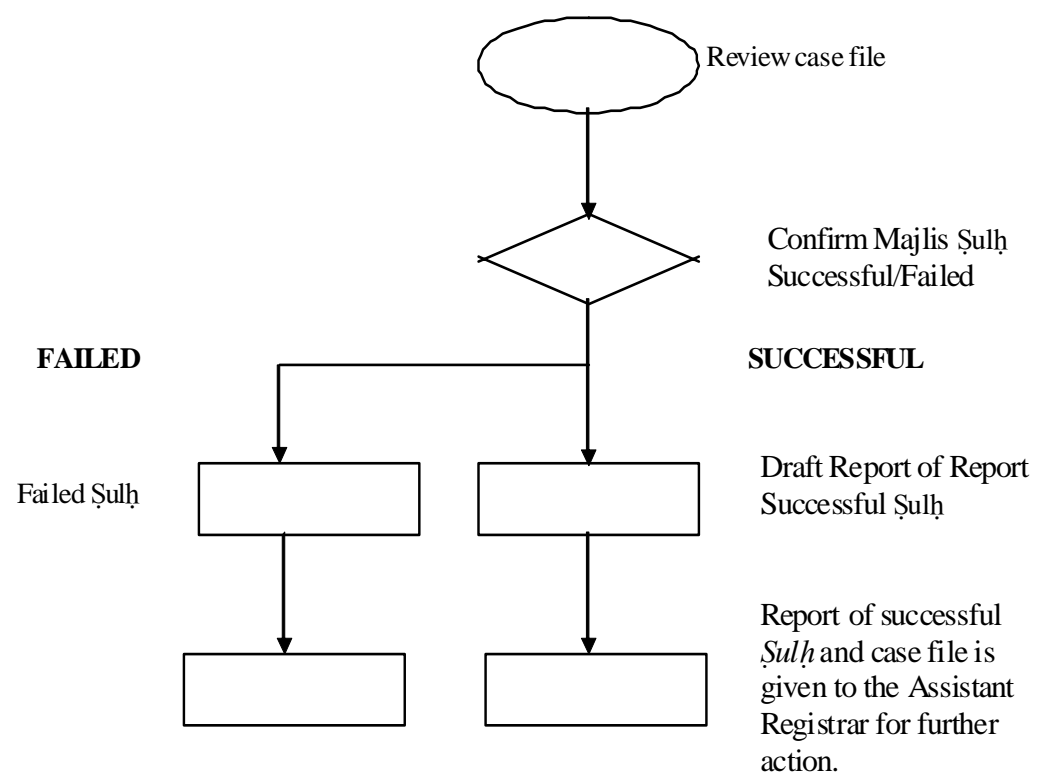

Source: Hulu Langat Lower Syariah Court

\section{Non-compliance and Retraction of Consent Order}

The validity of any agreement between the parties in sulh depends on whether it has been endorsed by the court or not. If the court has endorsed the agreement as consent judgment, it is valid for enforcement and non-compliance will amount to contempt of court. This is provided by Part XXIV of the Syariah Civil Procedure Enactment (Selangor) 2003. ${ }^{57}$ However, there are isolated instances of non-

$57 \quad$ Explanation to the same effect was also given by Norhadina Ahmad Zabidi, Director, Training Division JKSM communication with researcher, $16^{\text {th }}$ July 2009. 
compliance and retraction of Consent Judgement. ${ }^{58}$ Many disadvantaged parties decide not to file for Enforcement Order because they:

- $\quad$ Do not want to experience again the hassle of going to the court. - $\quad$ Cannot afford to incur further expenses.

- $\quad$ Do not know that such action can be taken.

Retraction of agreement usually happens when the agreement is about to be endorsed by the court. ${ }^{59}$ In other words, when both parties are asked whether there is mutual consent to the agreement, both or one of them claim otherwise. When this happens, the court will not endorse the agreement and the dispute will regress as unresolved. It is observed that dissatisfaction with the agreement achieved and third party intervention such as from relatives, friends or even the syariah lawyers may constitute factors that influence parties to retract consent agreement. ${ }^{60}$ At present, there is a Family Support Division at the Syariah Court that will help in tracing the parties in default and providing financial help to parties aggrieved by the default. ${ }^{61}$

\section{QUALIFICATION OF ȘULH OFFICER}

The duty of Sulh Officer is to resolve disputes according to the Islamic law. In order to achieve this, he or she needs to be knowledgeable in law and have necessary skills of a good mediator. The qualification for Șulh Officer is as follows: ${ }^{2}$

- $\quad$ Obtained Degree in Syariah from local or international universities, or

58 Siti Noraini Mohd Ali, șulh officer in Gombak Timur Lower Syariah Court, interviewed by the researcher, $19^{\text {th }}$ September 2007; Mohamad Ridzuan Zainudin, n. 37; Abdul Halim Abu Samah, n. 40; Azmi Abdul Aziz, șulh officer in Klang Lower Syariah Court, correspondence with the researcher August 2007.

59 Ibid.

60 The observation was confirmed by Siti Noraini Mohd Ali, n. 58; Mohamad Ridzuan Zainudin, n. 37; Abdul Halim Abu Samah, n. 40; Azmi Abdul Aziz, n. 58.

$61 \quad$ Norhadina Ahmad Zabidi, n, 57.

$62 \quad$ Ibid; Siti Noraini Mohd Ali, n. 58. 
- $\quad$ Obtained Diploma in Administration and Islamic Judiciary from the International Islamic University, Malaysia or University Kebangsaan Malaysia, or

- $\quad$ Obtained Certificate for Conducting Mediation from Mediation Consultants recognized by the Department of Syariah Judiciary Malaysia, or

- $\quad$ Appointed as Syarie Officer (Grade LS41).

In Selangor all Șulh Officers fulfill the above requirements. There are twelve Șulh Officer in Selangor, nine males and three females. From these twelve officers, four are assigned at the High Court in Shah Alam (two full time Sulh Officers and two Research Officers who will take over the duty to conduct Majlis Șulh if any one of the Șulh Officers is unavailable). It is also observed that there are inadequate Șulh Officers in Selangor. At present there are three courts without Sulh Officers: Lower Syariah Court of Sabak Bernam, Lower Syariah Court of Hulu Selangor and Lower Syariah Court of Sepang. ${ }^{63}$ This undoubtedly causes delay in resolving disputes because Majlis Șulh can only be conducted if and when Șulh Officers from other courts are available and can appear in these courts. ${ }^{64}$ Therefore, there is a need to increase Șulh Officers so that the problem of inadequacy of Șulh Officers and the delay in resolving cases through sulh can be settled.

\section{CONCLUSION}

Sulh has been proven to be very effective in reducing the caseload in the Syariah Courts of Selangor. ${ }^{65}$ The provisions pertaining to sulh in the state of Selangor can be found in sections 47 and 48 of IFLE 2003; sections 94, 99 and 131 of SCCPE 2003 and last but not least, rules in SCCPSR 2003. It is perceived that șulh has been used to

$63 \quad$ Previously there was Sulh Officer in the Lower Syariah Court of Sepang. However she was transferred to the Lower Syariah Court of Kuala Selangor.

64 This is affirmed by Norhadina Ahmad Zabidi, n. 57.

65 “Ṣulh Cara Terbaik Selesai Pertikaian Keluarga,” Berita Harian $26^{\text {th }}$ May, 2003, 6. 
resolve cases or claims relating to responsibility in marriage such as outstanding maintenance as well as cases or claims arising out of divorce such as mut'ah, harta sepencarian, 'iddah maintenance, had̄anah and maintenance of children. Thus, it can be implied that the responsibility of Șulh Officers is mainly to conciliate rather than to reconcile the parties in dispute. ${ }^{66}$

It is also noted that the Șulh Officers are governed by the Șulh Work Manual (the Manual) and the Ethical Code of Sulh Officer (the Code) provided by JKSM. The Manual serves as a standard that defines Sulh Officers or mediator's role, guiding them in their day-to-day practice and protect parties in disputes (consumers) as well as the credibility of the profession. On the other hand, the Code prescribes ethics of Șulh Officers. ${ }^{67}$ Thus, these rules assist Șulh Officers in performing Majlis Șulh while regulating their conduct.

The initiative taken by JAKESS in introducing sul $h$ in civil cases shows that amicable settlement of disputes should go hand in hand with litigation in court. This implies that disputants should be given the option to choose the method of settling their disputes. Disputants will only know that there is an alternative to litigation if they are informed about it. It is good that in Selangor the disputants are directed to sul $h$ by the court. When the parties register their cases in court, they are informed about the availability of sulh as an alternative method to settle their disputes. Sulh will only be conducted when both parties give their consent to it. This undoubtedly opens the opportunity to the disputing parties for options: either resolving their conflict through normal adjudication process or through an alternative mechanism in the form of șul h.

\footnotetext{
66 The Syariah Officer in Counselling Unit, Department of Islamic Religion bears the responsibility of reconciling disputing parties in marriage.

67 Sulh Officers who failed to comply with the manual and the Code will be subjected to disciplinary action under Civil Servant Rules (Behaviour) 1993.
} 